\title{
Modeling the Hydrological Impacts of Vegetation Cover Changes in the Upper Oum Er-Rbia Watershed (Morocco)
}

\author{
Msaddek Mohamed ${ }^{*}$, El Garouani Abdelkader1', Kimbowa George ${ }^{2}$ \\ 1 Faculty of Sciences and Techniques, Sidi Mohamed Ben Abdellah University, Laboratory of Functional \\ Ecology and Environmental, Route Imouzzer, Fez, Morocco \\ 2 Wageningen University and Research, Water Resources Management Group, Wageningen, Netherlands \\ * Corresponding author's e-mail: simo.msaddek@gmail.com
}

\begin{abstract}
In Morocco, the mountainous areas are often exposed to bulky and vicious flows of water and sediment. This process is exacerbated by the decrease in vegetation cover and the disruption in rainfall-runoff conditions that frequently cause significant flooding. By exploring the main hydrologic elements of these processes, it is possible to understand the behavior and hydrological response of watersheds and thus plan accordingly. In this study, the authors focused on determining the morphometric characteristics of the upper Oum Er-Rbia River basin (UOERRB by assessing/ evaluating the land use and land cover changes for a period of 32 years (1984-2016). Hydrologic Engineering Center's Hydrologic Modeling System (HEC-HMS) was applied to simulate four daily hydrological events. The concentration time was 7.7 hours. The four storm events examined to calibrate and validate the simulated outflow at the outlet indicated a good agreement between the hydrographs of the measured and simulated flows, with an average Nash-Sutcliffe efficiency (NSE) value ranging from 0.63 to 0.76 . Between 2002 and 2016, an average 6.21 percent increase in vegetation cover of with annual rainfall increasing from 690 to $714.1 \mathrm{~mm} /$ year was observed. These results can contribute to a better understanding of the hydrologic processes and better estimation of the return flows and thus guiding management decisions and developments in the UOERRB.
\end{abstract}

Keywords: Hydrological modeling, Vegetation cover, Remote sensing, HEC-HMS, Upper Oum Er-Rbia watershed, Morocco

\section{INTRODUCTION}

For arid and semi-arid countries, there is high anthropogenic pressure on watersheds due to land mis-use, over-exploitation of forests and unsustainable agricultural practices among other causes. This often results in rapid runoff, reducing infiltration and sometimes increasing soil erosion (Dregne, 2002; Ezeaku and Alaci, 2008; Pachauri et al., 2014; Yjjou et al., 2014).

Loumagne et al. (1991) noted that land use is one of the key parameters influencing soil erosion in steeply sloping landscapes and often disrupts the rainfall-flow relationships. The soil characteristics and the distribution of surface runoff due to diverse management practices are key determinants of the significance soil loss in a particular watershed (Kosmas et al., 1997; Marchandise,
2007). The relationship between the vegetation cover and hydrological processes is an important factor in maintaining soil against erosion and mitigating the flood risk (Rey et al., 2004).

The Upper Oum Er-Rbia River Basin (UOER$\mathrm{RB})$, experienced significant changes in land-use and land cover since 1984 to 2016. A significant change in UOERRB climate is causing a disruption of rainfall intensities and amounts (Driouech, 2010; El Ghachi, 2018). The cause-effect relationships between soil types, land cover, land use patterns and hydrological behavior has been studied by several researchers for instance (Chaponnière, 2005; Carlson et Arthur, 2000; Laborde, 2000; Kingumbi, 2006; Rey et al., 2004).

Remote sensing and geographic information systems are among the recent modern tools used for studying complex environmental phenomena 
at different spatio-temporal scales. Landsat satellites provide the data that is required in mapping and analyzing land cover (Kumar et al., 2020; Obodai et al., 2019). On a global scale, high spatial resolution sensors such as TM, ETM+ and Oli from Landsat satellites have been widely used for land cover mapping of large watersheds with limited accuracy (Hansen and Loeland, 2012). For this study, HEC-HMS (Hydrologic Engineering Center-Hydrologic Modeling System) model was used to simulate the water runoff process in the upper watershed of Oum Er Rbia. In order to calculate the runoff volume, peak flow, unit hydrograph, SCS curves and routing methods were used. The runoff simulation is based on four (4) randomly chosen rainfall events from thirty years of data (1984-2015). Out of the four events, three were selected for model calibration and one for validation. Several criteria were used to judge the effectiveness of the simulated models, including: the coefficient of determination $\mathrm{R}^{2}$, ratio of the root mean square error to the standard deviation of measured data (RSR) and the Nash-Sutcliffe Efficiency (NSE). The main aim of this study was to explore the spatio-temporal land use and land cover (LULC) changes in UOERRB and its effect on hydrology for 1984 and 2015 based on remote sensing data. Using the HEC-HMS model to simulate event scenarios and predict basin response allows planning for the events that can result in destructive floods and damages at the watershed level.

\section{MATERIALS AND METHODS}

\section{Study area}

The study area is part of the large watershed of the Oued Oum Er-Rbia which has its source at an altitude of $1800 \mathrm{~m}$ at $47 \mathrm{~km}$ from the city of Khénifra (Figure 1). It is located between latitude $33^{\circ}$ and $33^{\circ} 5^{\prime}$ North and longitude $5^{\circ} 01^{\prime}$ and $5^{\circ} 08^{\prime}$ West. UOERRB covers an area of $1049 \mathrm{Km}^{2}$, with the outlet located at the Tahrat meteorological station. at the level of the upstream part on the left bank, UOERRB is hydrologically fed by several small tributaries born from the springs which gush out at the foot of the Atlas and some wadis the basins of which develop on small surfaces.

The upstream part of UOERRB is mountainous with altitudes ranging between $864 \mathrm{~m}$ and $2400 \mathrm{~m}$, characterized with a diversity of reliefs and geological formations. The main substrates encountered in the basin are Paleozoic schists and quartzites, Triassic basalts and red clays, Lias, limestones and dolomites as well as Quaternary alluvium and colluvium (Bouabdelli and Piqué, 1996). The average annual runoff of UOERRB at upstream and downstream stations is $0.9 \mathrm{~m}^{3} / \mathrm{s}$ (Tamchachat) and $21 \mathrm{~m}^{3} / \mathrm{s}$ (Tahrat), with a moderated weak correlation between the two stations.

\section{Methodology}

The morphometric characteristics of the basin were calculated based on $30 \mathrm{~m}$ resolution ASTER-DEM (Advanced Space borne Thermal Emission and Reflection Radiometer-Digital Elevation Model) data, and topographic maps of Khenifra, Mrirt, Krrouchen, Timahdite, El Hammam and Itzer at scale 1/50000. These datasets were used to delineate the watershed and to calculate the map of slopes, altitude ranges, $\mathrm{KC}$ index, time of concentration, etc.

The assessment of the land-use and land cover changes (LULCC) was based on 15 satellite images of Landsat sensors for the dates $(1984,1987$, 1988, 1994,1995, 2000, 2001, 2002, 2006, 2007, $2009,2010,2011,2015,2016)$. For reliability and accuracy of the LULCC results, the images taken during the summer months (June, July and August), with minimal effect of cloud cover, were selected. The satellite sensors used are: Landsat5 TM (8 images), Landsat7 ETM+ (5 images) and Landsat8 OLI (2 images).

The nature of the soil influences the rise of floods, the infiltration rate, the retention capacity and the initial losses. The UOERRB soils were classified based on the SCS classification method that allocates soils into four hydrological groups (A, B, C, D) based on the estimates of their infiltration potential (Arlen D, Feldman). The existing soil map was completed in the eastern part, and subsequently each unit was assigned to soil type classes.

The hydrometric data were analyzed using the R software. The categories of flows exceeding $25 \mathrm{~m}^{3} / \mathrm{s}$ and their corresponding rainfall were identified and correlations between these different events were sought.

The rainfall-runoff relationship was simulated using the HEC-HMS model taking into account the SCS (Soil Conservation Service) production function, Curve Number Loss and the SCS (Unitary Hydrograph) transfer function. This method 


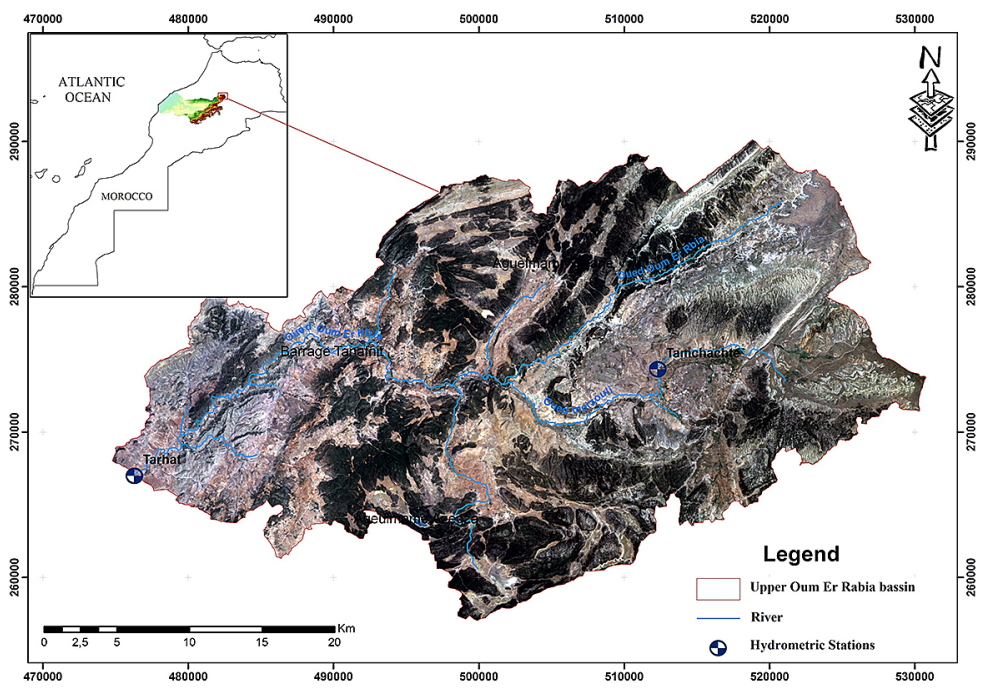

Figure 1. Geographical location of the upper Oum Er-Rbia Basin

was chosen due to its robustness in reproducing the rainfall-runoff relationship in several contexts, especially in semi-arid areas, besides limited rainfall stations in the UOERRB.

Hydrological and morphometric parameters, such as surface, slope, sub-watershed boundary and hydrographic network, were calculated using ArcGIS 10.3 software and its extensions Arc Hydro and HEC-GeoHMS. Remote sensing image processing, such as geometric and atmospheric corrections, NDVI calculation, supervised image classification was performed by means of ENVI 5.1 (Environment for Visualizing Images) software. The general methodology adopted for this study is shown in (Figure 2).

The method used for atmospheric correction is Dark Object Subtraction (DOS) a simple empirical atmospheric correction method which

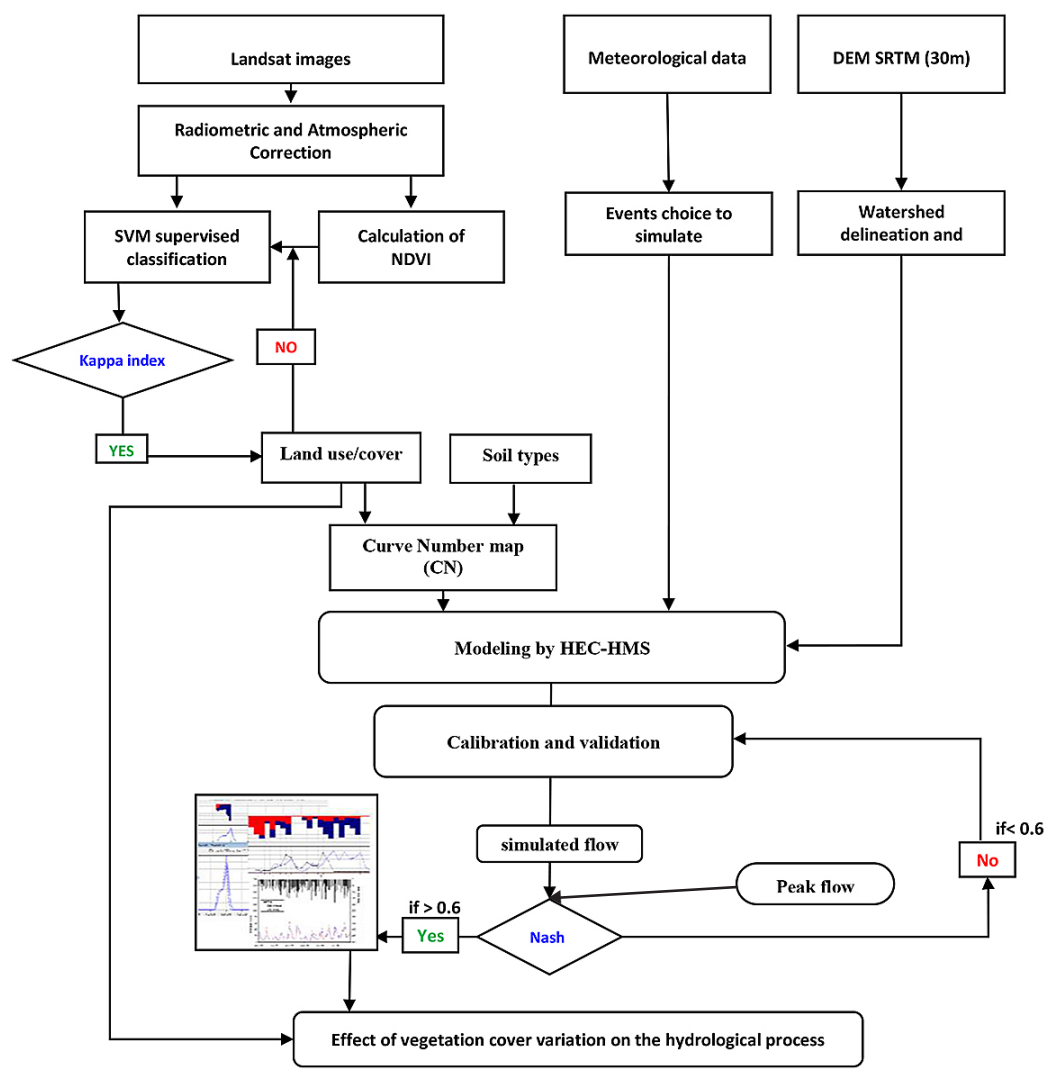

Figure 2. Study methodology 
assumes that the reflectance of dark objects includes a significant component of atmospheric scattering (Gilmore et al., 2015).

Support Vector Machine (SVM) classification was used to distinguish the five land cover classes (bare soil, water surface, dense forest, less dense forest, and sparse forest) of the study area.

\section{RESULTS AND DISCUSSION}

\section{Physical characteristics of the basin}

The component features of UOERRB were calculated through morphometric analysis (Table 1). The digital terrain model (DTM) shows that the altitudes of the upper Oum Er Rbia basin vary between $800 \mathrm{~m}$ and $2400 \mathrm{~m}$ in the SouthWestern and North-Eastern part of the basin respectively. The UOERRB is characterized by a predominance of low and medium slopes, with slope classes below 0.2 covering approximately $82 \%$ of the total watershed area. The compactness index $(\mathrm{KG})$ is 2.2 , reflecting an elongated basin shape; therefore, the average water concentration time is 7.71 hours. The difference in

Table 1. Morphological characteristics of the upper Oum Er Rbia basin

\begin{tabular}{|l|c|}
\hline Surface area $\left(\mathrm{km}^{2}\right)$ & 1049.00 \\
\hline Length $(\mathrm{km})$ & 54.65 \\
\hline Perimeter $(\mathrm{km})$ & 255.44 \\
\hline Max altitude $(\mathrm{m})$ & 2400.00 \\
\hline Min. altitude $(\mathrm{m})$ & 860.00 \\
\hline Average altitude $(\mathrm{m})$ & 1637.10 \\
\hline Elevation gain $(\mathrm{m})$ & 1540.00 \\
\hline Slope $(\mathrm{m} / \mathrm{km})$ & 13.01 \\
\hline Equivalent length & 118.38 \\
\hline Equivalent width & 8.86 \\
\hline Kc Index & 2.20 \\
\hline Average slope & 12.97 \\
\hline
\end{tabular}

elevation is $1540 \mathrm{~m}$, which facilitates the circulation of water within the basin.

\section{Analysis of the rainfall-flow relationship}

It is necessary to have reliable and precise information on extreme rainfall events in terms of flood risk in the watershed for better management of water resources. The analysis of the rainfall and hydrometric series was carried out with the aim of qualifying the homogeneity of rainfall and flow on a spatio-temporal scale. The two stations used are Tamchachat (upstream station) and Tahrat (downstream station). The hydro-meteorological data are provided by the Agency of the Hydraulic Basin of Oum Er Rbia (ABHOR).

The wettest months at both stations are between November and February. The driest months are June, July and August. Comparing the precipitation in these two locations, it was found that both stations have the same precipitation pattern and a significant difference in flow rates between upstream and downstream; this is explained by the fact that the Tamchachat station is located on a stream upstream with a low flow. The average interannual flow at the Tahrat station is $21 \mathrm{~m}^{3} / \mathrm{s}$, while that of the Tamchachat station does not exceed $0.9 \mathrm{~m}^{3} / \mathrm{s}$ (Figure 3 ).

In order to assess the quality of precipitation in the UOERRB on a spatio-temporal scale between the downstream (Tamchachat) and upstream (Tahrat) stations, daily rainfall was analyzed. The correlation between daily rainfall at Tahrat and Tamchachat is moderate (Figure 4) with a correlation coefficient of 0.67 . In addition, Tamchachat recorded more rainfall than Tahrat due to the differences in altitude.

\section{Type of soil}

In order to determine the amount of surface runoff in a watershed using the SCS-CN method,

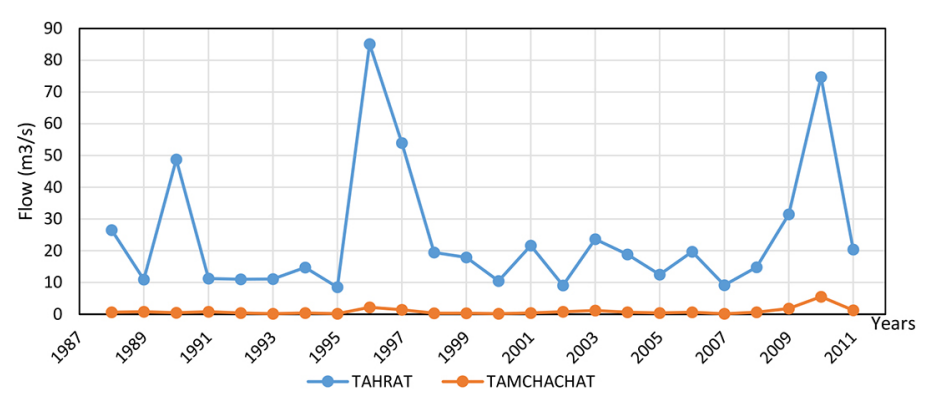

Figure 3. Average interannual flows 1988/2011 

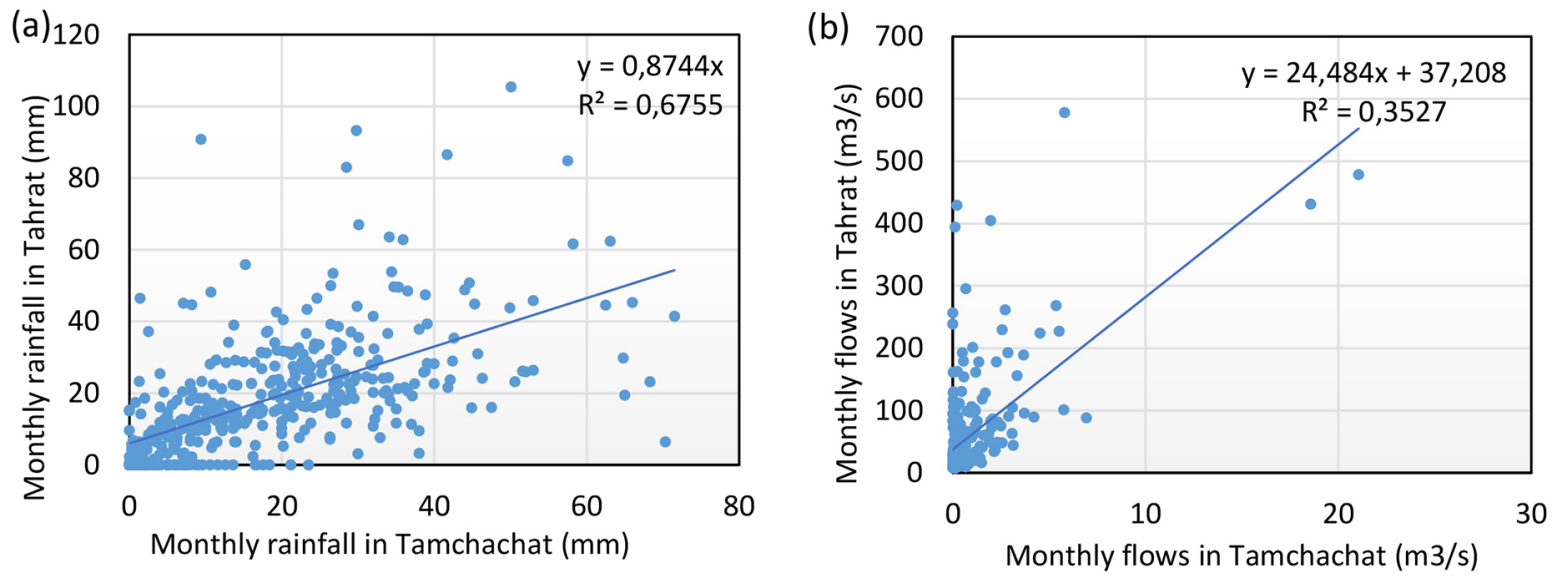

Figure 4. Correlation between monthly precipitation (a); correlation between monthly flow (b) of Tahrat and Tamchachat (1990 to 2000)

several factors are considered, including soil type, land use, and previous soil moisture (Uwizeyimana et al., 2019).

The soil texture of UOERRB was extracted from the soil map established by the Provincial Directorate of Agriculture (DPA) Khenifra (1987). The analysis of the map shows that the dominant textures are red clay of Trias and calcareous silt. The main types of soils in the watershed are little evolved soils, A sesquioxides, Isohumic, Vertisols, Calcimagnesic and Crude Minerals.

The soil types were classified into hydrological soil groups (A, B, C and D) indicating the infiltration rate for bare soil after prolonged wetting (Figure 5). Soil groups A and D cover the largest surface area of $476.93 \mathrm{~km}^{2}$ and $241.84 \mathrm{~km}^{2}$, respectively. Soil groups B and C cover $95.7 \mathrm{Km}^{2}$ and $234.77 \mathrm{Km}^{2}$, respectively. The corresponding runoff potential is low, moderate, medium and high for soil groups A, B, C, and D, respectively.

\section{Land use mapping}

The LULC in UOERRB was carried out by classifying the mapping of Landsat images for the selected dates. Figures 6 and 7 illustrate the distribution of land cover classes from the year 1984 to the year 2016. A remarkable change in LULC during the last 32 years was noted. Between 2002 and 2016, there was a significant increase in vegetation cover. This corresponds with the average annual precipitation increased during the period 2002-2015 (from 690 to $714 \mathrm{~mm} /$ year), and thus can be partly explained by the increased reforestation rates during the last decades to replenish the degraded lands in UOERRB.

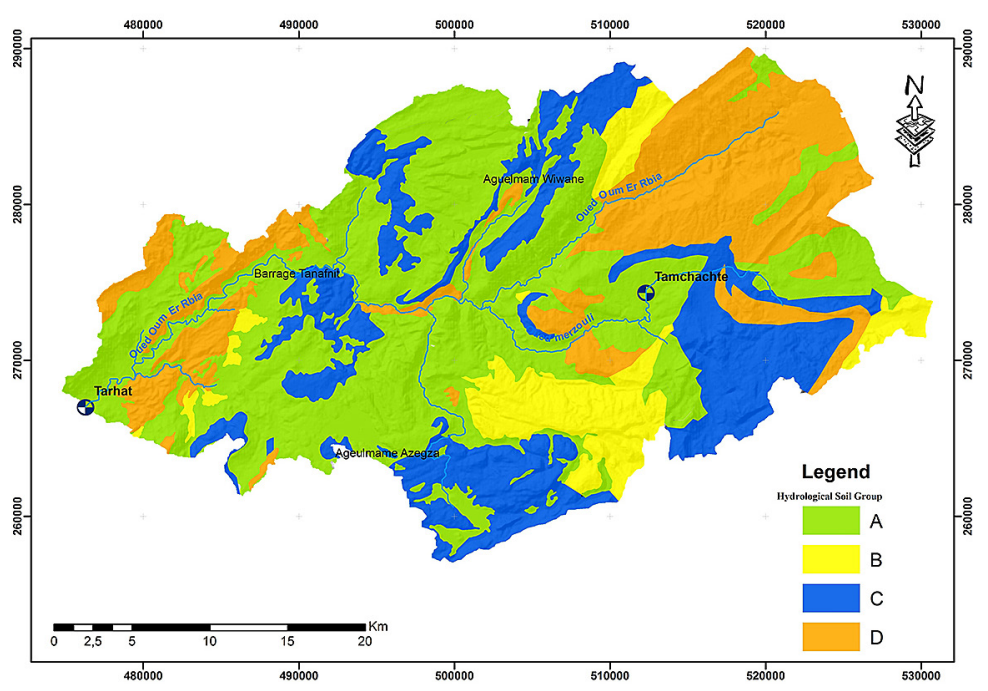

Figure 5. UOERRB Soil Hydrologic Class (HSG) Map 

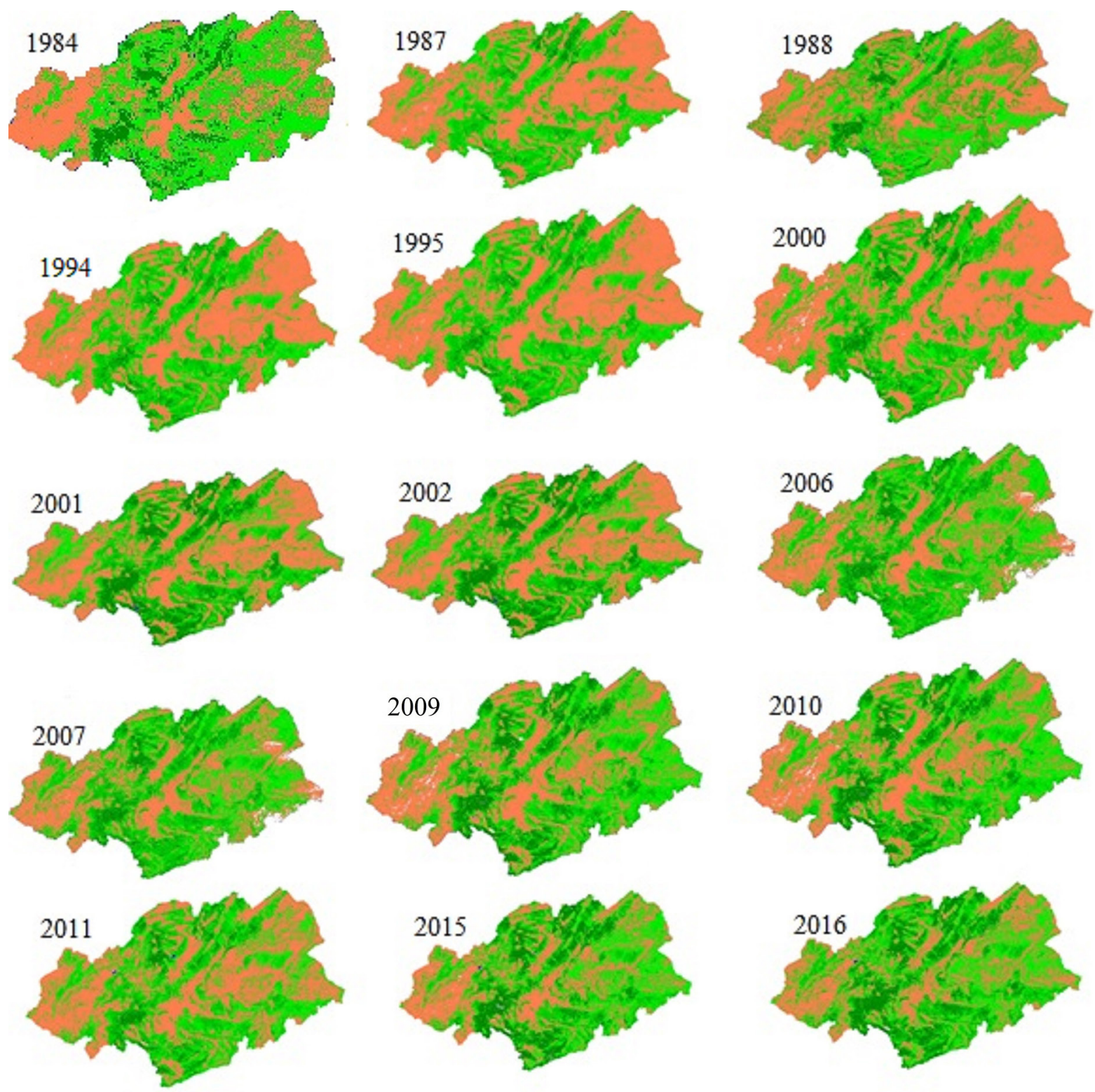

Legend

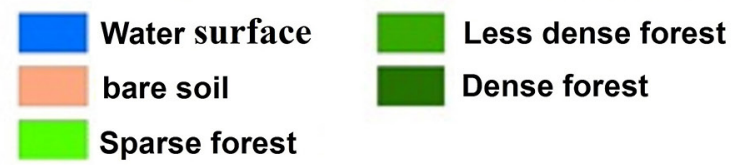

Figure 6. Land use map assemblies from 1984 to 2016

The generated LULC maps represent five classes, namely bare soil, water surfaces, dense, less dense, and sparse forest. Figure 8 represents an example of land cover mapping from the July 23, 2015 Landsat8 image. The dominant LULC class category is bare soil, occupying $40 \%$ of the basin area with very little urban fabric in the form of dispersed villages. The different classifications were evaluated by the confusion matrix and through the calculation of the Kappa coefficient as well as the overall classification accuracy which is between $70 \%$ and $80 \%$.

Table 2 represents the confusion matrix calculated for the classification of the Landsat7 ETM image of $23 / 07 / 2015$. The Kappa coefficient is 0.75 , and thus the classification is acceptable.

According to this matrix, there is some confusion, for example, between less dense forest and dense forest as well as between less dense forest and sparse forest. 


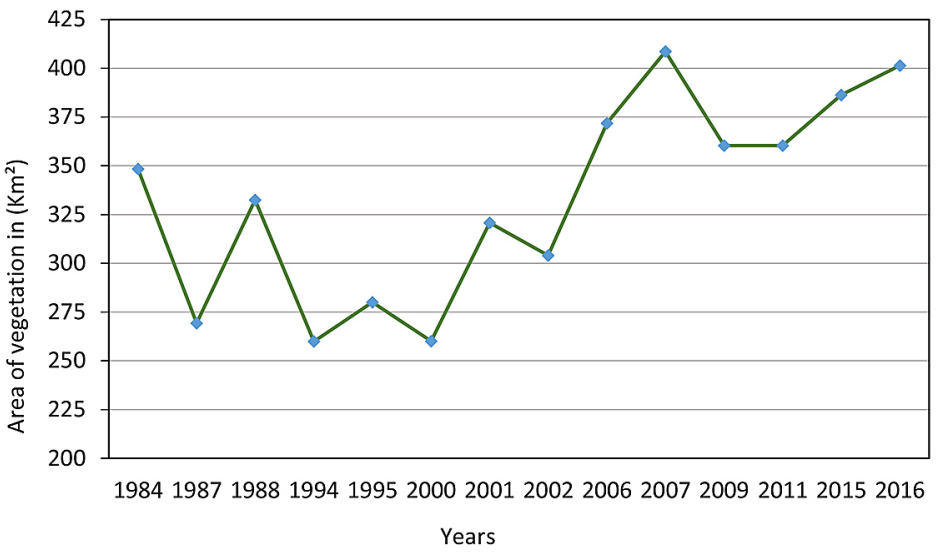

Figure 7. Evolution of the vegetation cover of the UOERRB

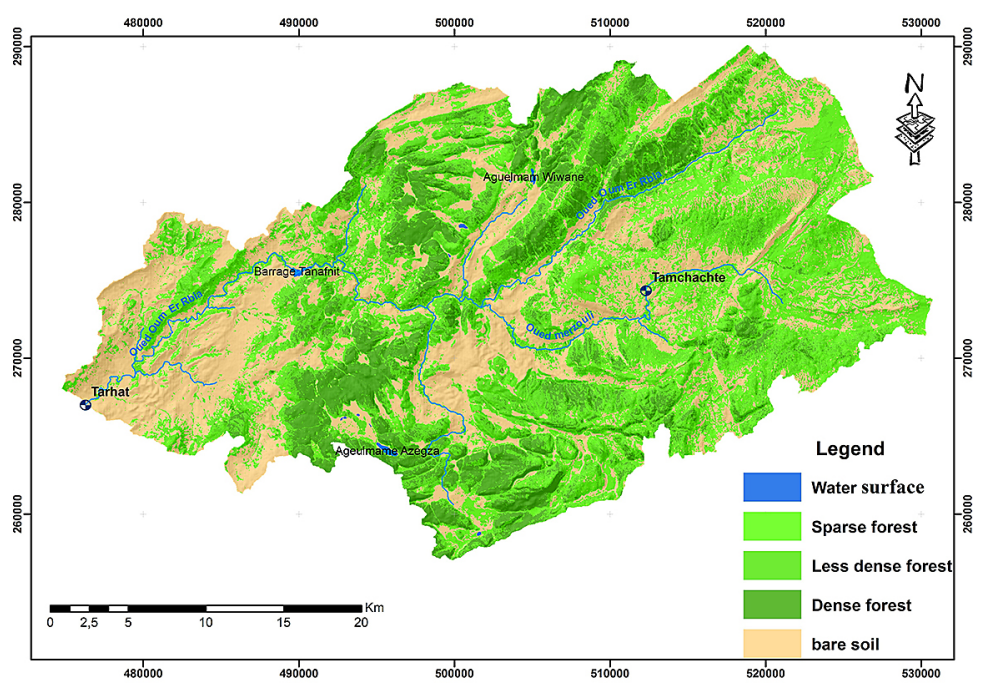

Figure 8. UOERRB land use map from 23/07/2015

\section{Curve Number (CN)}

In order to model rainfall events in the upper Oum Er Rbia basin, the Soil Conservation Service-Curve Number (SCS-CN) method developed by the United States Department of Agriculture (USDA) (Musy and Higy, 1998; Muthu and Santhi, 2015) was used. This method is effective and widely used to determine the amount of water runoff. The Curve Number model estimates excess precipitation as a function of cumulative rainfall from the soil cover and initial soil moisture. The runoff estimation is as presented equation (1):

$$
Q=\frac{(P-I a)^{2}}{P-I a+S}
$$

Table 2. Confusion matrix of the classification of the Landsat ETM image of 23/07/2015.

\begin{tabular}{|c|c|c|c|c|c|c|c|}
\hline Class/Ref & $\begin{array}{l}\text { Water } \\
\text { surface }\end{array}$ & $\begin{array}{c}\text { Bare } \\
\text { soil }\end{array}$ & $\begin{array}{c}\text { Dense } \\
\text { forest }\end{array}$ & $\begin{array}{l}\text { Less dense } \\
\text { forest }\end{array}$ & $\begin{array}{l}\text { Sparse } \\
\text { forest }\end{array}$ & $\begin{array}{c}\% \text { error } \\
\text { omission }\end{array}$ & Precision producer \\
\hline Water surface & 72 & 0 & 0 & 0 & 0 & 0.0 & 100.0 \\
\hline Bare soil & 0 & 30 & 0 & 0 & 0 & 0.0 & 100.0 \\
\hline Dense forest & 0 & 0 & 63 & 0 & 0 & 0.0 & 100.0 \\
\hline Less dense forest & 0 & 0 & 0 & 0 & 2 & 1.0 & 99.0 \\
\hline Sparse forest & 0 & 21 & 0 & 18 & 11 & 0.8 & 99.2 \\
\hline Error \% Commission & 0.0 & 0.4 & 0.0 & 1.0 & 0.2 & 81.10 & Overall accuracy (\%) \\
\hline User accuracy & 100.0 & 99.6 & 100.0 & 99.0 & 99.8 & 0.751 & Coefficient of kappa \\
\hline
\end{tabular}


where: $Q$ : total runoff (mm)

Pe: total precipitation $(\mathrm{mm})$

Ia: initial loss (mm)

$S$ : maximum retention potential $(\mathrm{mm})$

There is also the following empirical relation

$$
\text { Ia }=0.2 \mathrm{~S}
$$

This gives us:

$$
P e=\frac{(P-0.2 S)^{2}}{P+0.8 S}
$$

Now the maximum retention potential $\mathrm{S}$ and the characteristics of the basin are related by the number of curve $\mathrm{CN}$ by:

$$
S=\frac{25400-254 C N}{C N}
$$

The Curve Number $(\mathrm{CN})$ is calculated on the basis of the hydrological soil group and land use. Curve Number values range from 30 to 100 . The higher the $\mathrm{CN}$ value, the greater the surface runoff.

The weighted $\mathrm{CN}$ value over the entire basin was calculated using the following equation:

$$
\mathrm{CN}_{\mathrm{w}}=\frac{\sum_{i} A i C N i}{A j}
$$

where: $C N_{w}$ : Weighted Curve Number

$A i$ : surface of the sub-basin

$A j$ : total surface of the basin

The SCS-CN method takes into account the initial soil moisture conditions that influence the soil capacity for runoff (SCS, 1972). Curve Number values were assigned to each soil unit corresponding to the intersection of land use and soil hydrological classes using the standard look- up table NRCS TRR55.

A great variation of $\mathrm{CN}$ values can be noticed in UOERRB (Figure 9), with low values (30-62) for permeable soils where dense forest is frequently found, and high values (64 and 90) for less impermeable soils; on the other hand, for water surfaces the maximum value is 100 .

\section{Modeling by HEC-HMS}

After the calculation of all the parameters necessary for the modeling (slopes, $\mathrm{CN}$, concentration time, Lag time, etc.), the schema created in HEC-GeoHMS that divided the basin into four sub-basins according to their degree of heterogeneity were exported (Figure 10).

In order to determine the values of the parameters that give a good simulation performance of the observed flood hydrographs, parameterization of the modules via the HEC-HMS software was performed by calculating the input parameters of each sub-basin (Table 3).

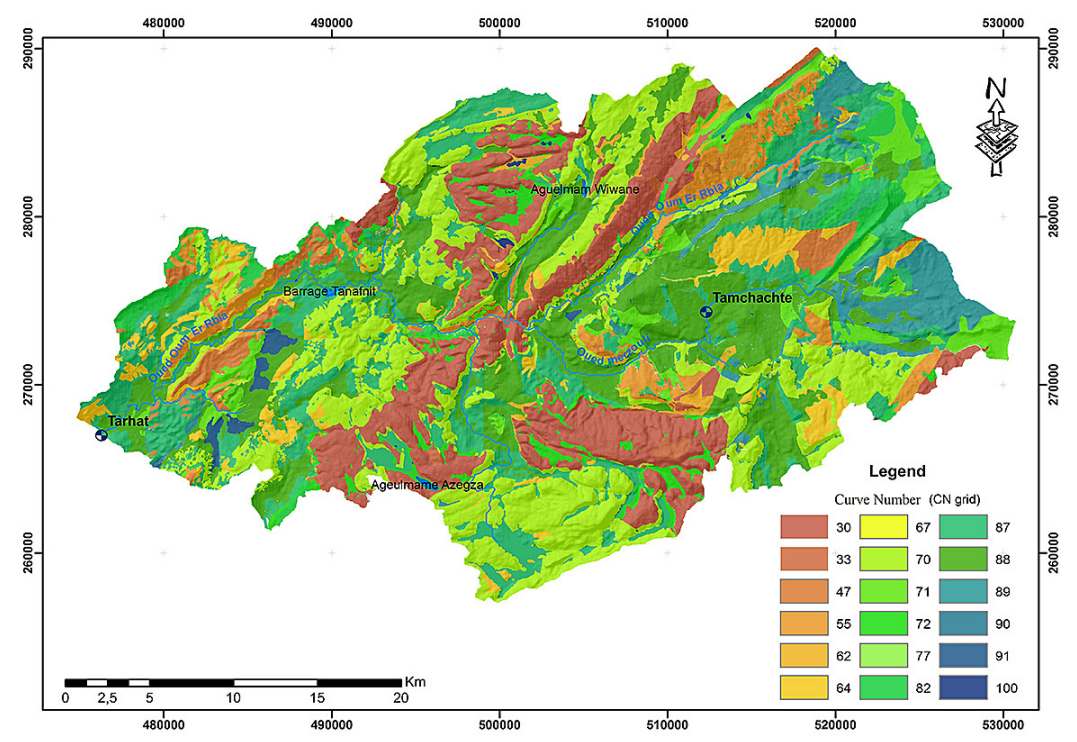

Figure 9. Curve Number Map of the UOERRB 
Table 3. Model input parameters

\begin{tabular}{|c|c|c|c|c|c|c|}
\hline $\begin{array}{c}\text { Sub-basin } \\
\text { number }\end{array}$ & Name & $\begin{array}{c}\text { Surface area } \\
\left(\mathrm{km}^{2}\right)\end{array}$ & CN & $\begin{array}{c}(\%) \\
\text { impervious }\end{array}$ & Initial abstraction (mm) & Tlag (min) \\
\hline BV1 & W250 & 278.00 & 78 & 54 & 14,33 & 77 \\
\hline BV2 & W220 & 271.61 & 73 & 34 & 19,27 & 60 \\
\hline BV3 & W240 & 133.73 & 76 & 20 & 16,48 & 61 \\
\hline BV4 & W230 & 366.61 & 75 & 29 & 17,39 & 66 \\
\hline
\end{tabular}

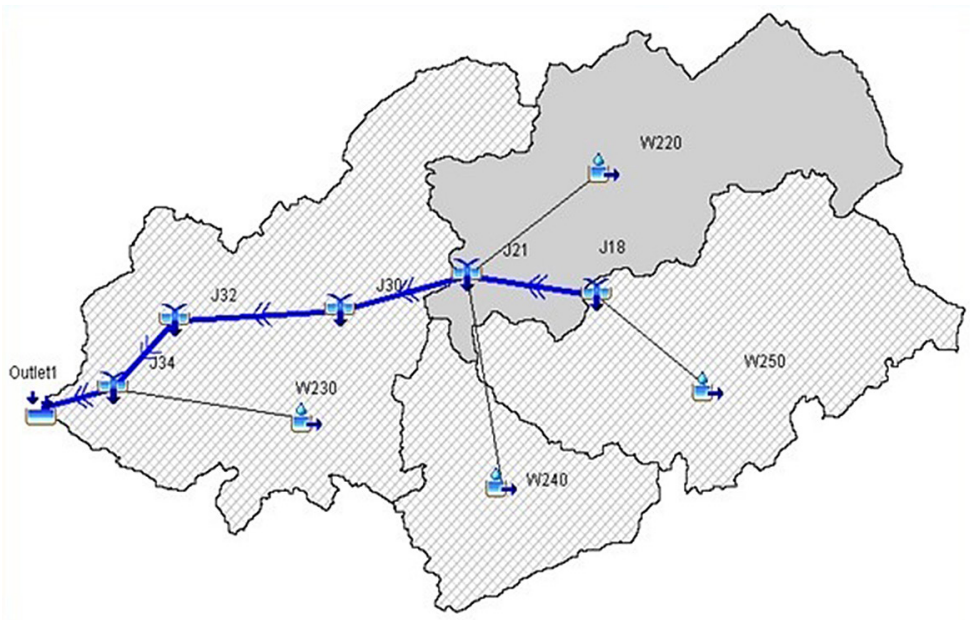

Figure 10. Model architecture used for the UOERRB

\section{Model calibration}

The model calibration was conducted using the objective function on the peak flow. In order to determine the sensitivity of the parameters, $\mathrm{CN}$, the Lag time, the impervious surface and the initial abstraction (Ia) were optimized by manually estimating the initial value of each parameter and change until obtaining a simulated flow close to the observed flow.

The four flood events were selected basing on the availability of datasets as presented in table 4 (three events for calibration and one for validation).

\section{Event 1}

For December 2000, the simulated flows correspond to the observed model, presenting well the general appearance of the observed flood. Indeed, the simulated peak flow is very close to the observed one in terms of peak and slightly shifted in terms of time (Figure 11).

\section{Event 2}

For December 01, 2001 to December 30, 2001 , it can be noticed that the general flood pattern is respected; the peak flow is well simulated in terms of time with an overestimation of the flow for the second peak (Figure 12).

\section{Event 3}

For the third event, it can be noted that the simulated flow rate corresponds with the observed flow rate, the peak flow rate is well simulated in terms of time and its value is very close to the observed value with minimal spikes, with an over estimation of the flow rate for the second peak, and an underestimation for the first and the third peak (Figure 13).

\section{Validation}

\section{Event 4}

The validation phase of the model aimed at ensuring that the flood hydrographs are reasonable and close enough to reality. It is a question of finding a peak flow in an independent way from

Table 4. Characteristics of the events used by the model

\begin{tabular}{|c|c|c|c|}
\hline $\mathbf{N}^{\circ}$ Events & Function & Start date & End date \\
\hline $\mathbf{1}$ & Calibration & $01-12-2000$ & $30-12-2000$ \\
\hline $\mathbf{2}$ & Calibration & $01-12-2001$ & $30-12-2001$ \\
\hline $\mathbf{3}$ & Calibration & $01-11-2002$ & $30-11-2002$ \\
\hline $\mathbf{4}$ & Validation & $01-11-2010$ & $30-11-2010$ \\
\hline
\end{tabular}




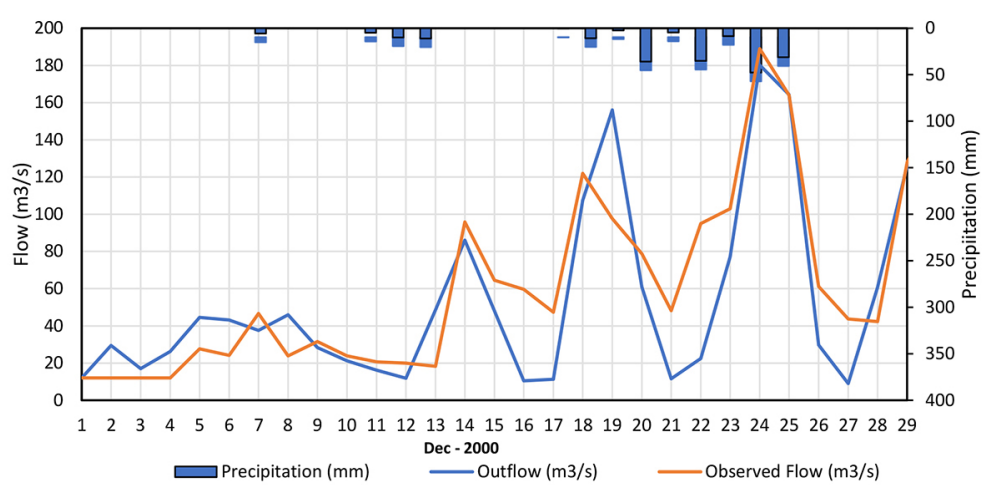

Figure 11. Flood hydrograph for event 1

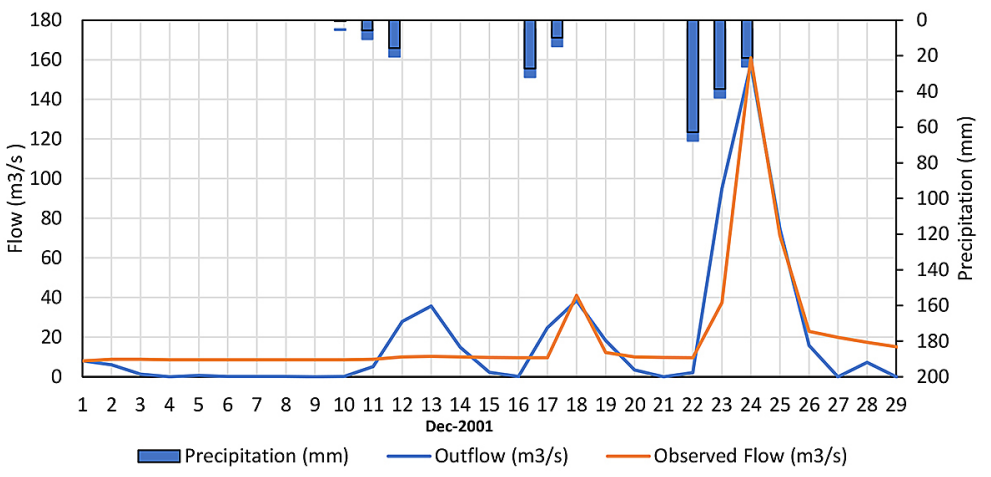

Figure 12. Flood hydrograph for event 2

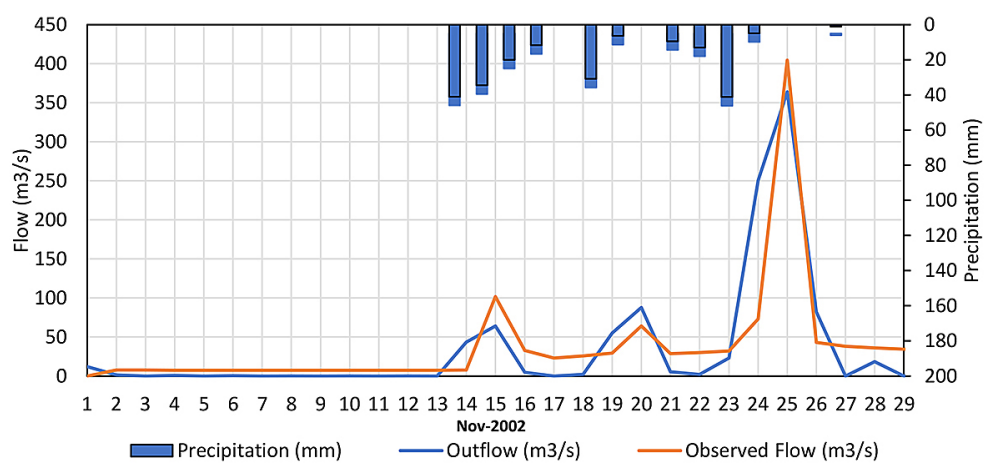

Figure 13. Flood hydrograph for event 3

the optimized calibration parameters. During validation in the $4^{\text {th }}$ event (Figure 14), the simulated flows match with the observed flows except for some fluctuation at the beginning with an underestimation of the peak flood.

It is generally noticed that the validation parameters tend towards the input parameters of the initial model, except for the Lagtime and the initial losses, there is a significant increase at the level of all the sub-basins, while for the $\mathrm{CN}$, the values are slightly modified and tightened between 73 and 80. For imperviousness, there is a decrease of $22 \%$ at BV1, while there is a slight increase for the other sub-basins (Table 5).

\section{Evaluation of the quality of the model}

Once the model is established, performance assessment is essential to determine its relevance and reliability. The evaluation is done based on standardized performance indicators/ parameters (i.e., calculate and judge against a reference value) (Table 6).

- The Nash-Sutcliffe criterion is a performance indicator, with values ranging between $-\infty$ and 1]. 
Table 5. Optimized model parameters

\begin{tabular}{|c|c|c|c|c|c|c|}
\hline Sub-basin number & Name & $\begin{array}{c}\text { Surface area } \\
\left(\mathrm{km}^{2}\right)\end{array}$ & $\mathrm{CN}$ & $\begin{array}{c}(\%) \\
\text { Impervious }\end{array}$ & $\begin{array}{c}\text { Initial abstraction } \\
(\mathrm{mm})\end{array}$ & Tlag (min) \\
\hline BV1 & W250 & 278 & 78 & 32 & 25 & 146 \\
\hline BV2 & W220 & 272 & 73 & 39 & 21 & 168 \\
\hline BV3 & W240 & 134 & 75 & 31 & 51 & 269 \\
\hline BV4 & W230 & 367 & 80 & 30 & 63 & 200 \\
\hline
\end{tabular}

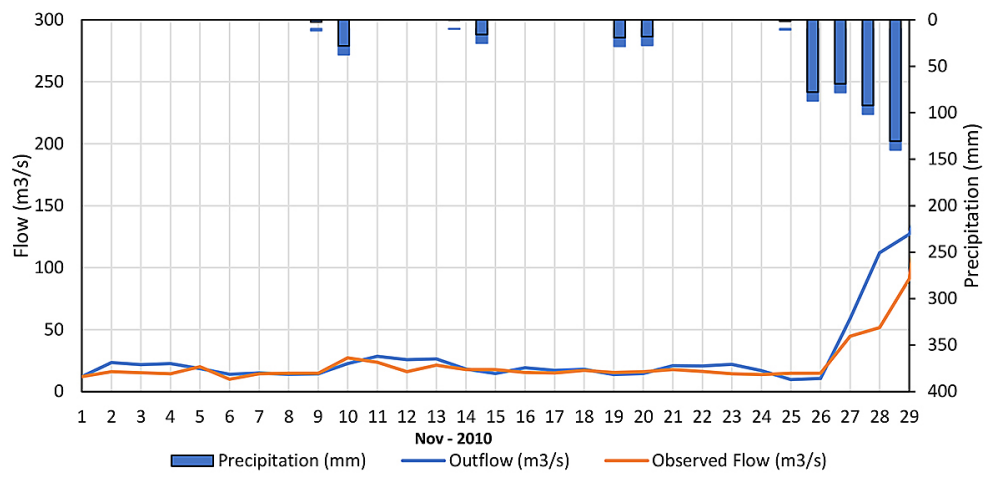

Figure 14. Flood hydrograph for event 4

The closer the value obtained for this criterion is to 1 , the better the simulation results (McCuen et al., 2006).

- RSR is a criterion similar to the Nash-Sutcliffe, but less used. It is based on the normalization of the RMSE instead of the MSE. The closer the value obtained for this criterion is to 0 , the better the result of the simulation.

- The correlation coefficient: it is based on the linear regression with the correlation coefficient. The latter gives the intensity of the linear relationship between the variables. This method is considered effective only when the correlation coefficient is high enough $(>0.75)$.

Nash-Sutcliffe and RSR provide the information on the total modeling error. From Table 7, it can be noticed that the model results are good for events 2 and 4, and satisfactory for events 1 and 3 . The stronger the correlation, the better the
Table 6. Model Quality Assessment Criteria

\begin{tabular}{|c|c|c|c|}
\hline EVENTS & NSE & RSR & $\mathrm{R}^{2}$ \\
\hline 1 & 0.656 & 0.341 & 0.711 \\
\hline 2 & 0.728 & 0.247 & 0.806 \\
\hline 3 & 0.693 & 0.297 & 0.752 \\
\hline 4 & 0.768 & 1.649 & 0.773 \\
\hline
\end{tabular}

simulation and this is explained by the correlation coefficient $\mathrm{R}^{2}$. In general, this parameter is satisfactory for events 1 and 4 with values of 0.711 and 0.752 , respectively, and fairly good for events 2 and 3 with values of 0.806 and 0.773 , respectively (Figure 15).

\section{Effect of vegetation cover on flood flows}

Figure 16 illustrates the relationship between peak flood flows and the amount of vegetation cover determined from Landsat images. It was

Table 7. Difference between volumes and flows of the four episodes of the selected flood

\begin{tabular}{|c|c|c|c|c|c|c|c|c|}
\hline \multirow{3}{*}{$\begin{array}{c}\text { Event } \\
\text { No. }\end{array}$} & \multirow{2}{*}{\multicolumn{2}{|c|}{ Peak flow $\left(\mathrm{m}^{3} / \mathrm{s}\right)$}} & \multirow{2}{*}{\multicolumn{2}{|c|}{ Peak flow date $\left(\mathrm{m}^{3} / \mathrm{s}\right)$}} & \multirow{3}{*}{ Difference } & \multicolumn{2}{|c|}{ Runoff volume (mm) } & \multirow{3}{*}{ Difference } \\
\hline & & & & & & \multirow{2}{*}{ observed } & \multirow{2}{*}{ simulated } & \\
\hline & observed & simulated & observed & simulated & & & & \\
\hline 1 & 180.2 & 189 & $24 / 12 / 2000$ & $24 / 12 / 2000$ & -4.7 & 129.06 & 147.00 & -12.21 \\
\hline 2 & 156.4 & 161 & $24 / 12 / 2001$ & $24 / 12 / 2001$ & -2.9 & 46.06 & 47.39 & -2.8 \\
\hline 3 & 363.9 & 404.5 & $25 / 11 / 2002$ & $25 / 11 / 2002$ & -10 & 82.86 & 91.22 & -9.17 \\
\hline 4 & 198.9 & 268.4 & $30 / 11 / 2010$ & $29 / 11 / 2010$ & -25.9 & 69.84 & 57.11 & 22.29 \\
\hline
\end{tabular}



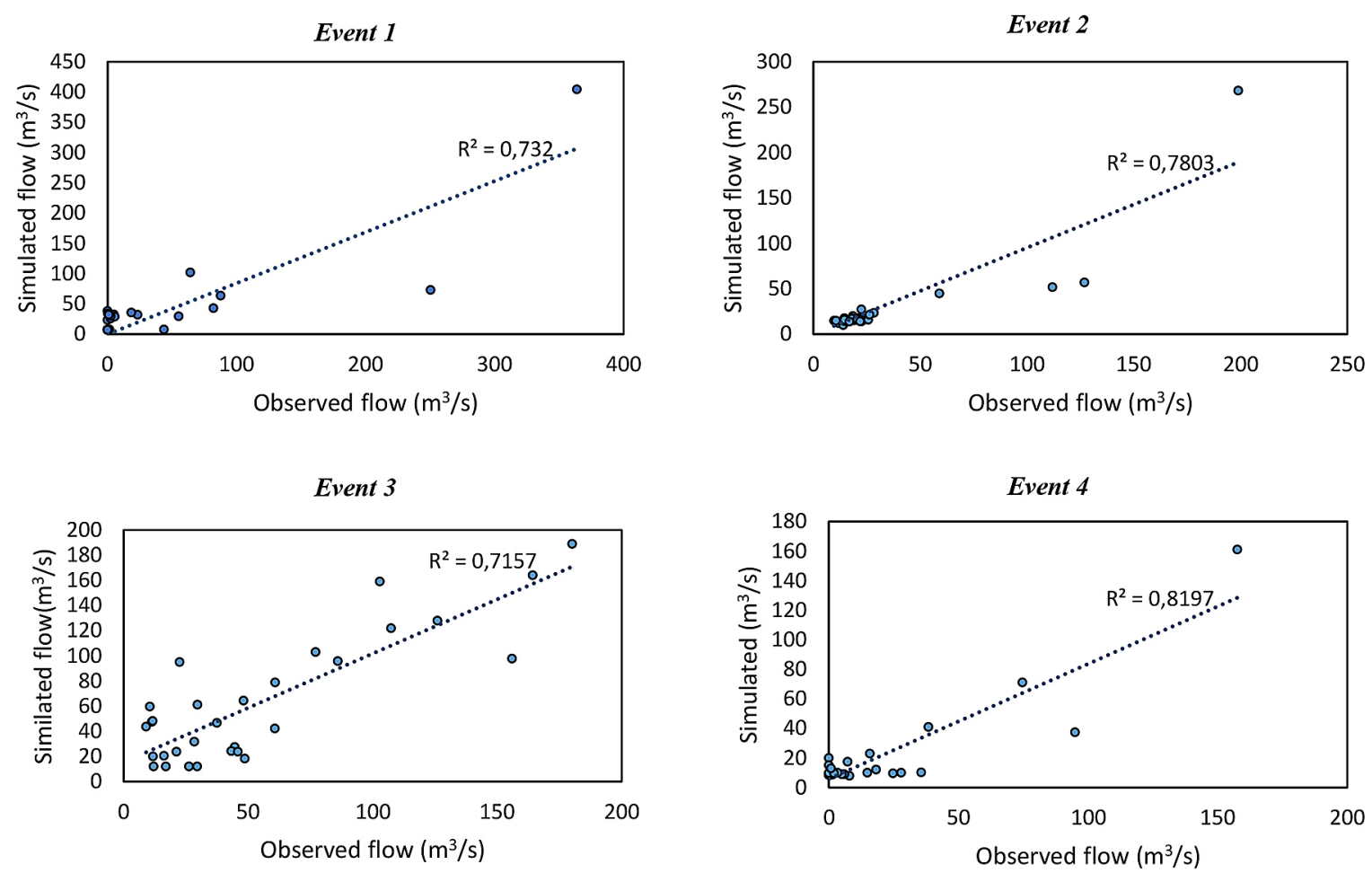

Figure 15. Correlation between observed and simulated flows of the 4 events used by the model

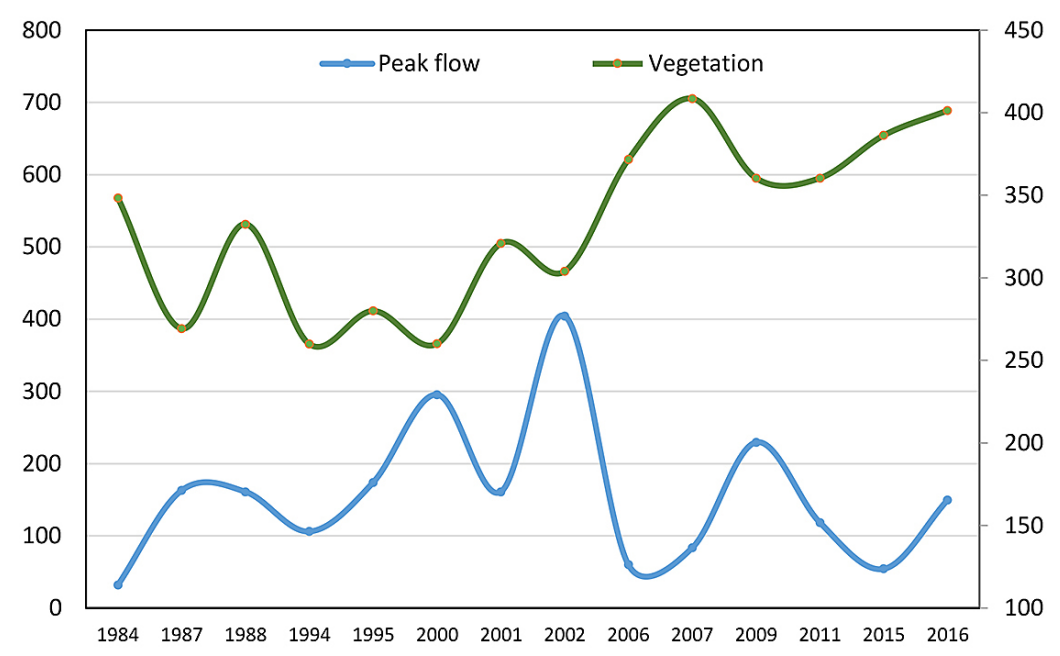

Figure 16. Relationship between changes in vegetation cover and peak flows

noted that the influence of the vegetation variation on the peak flow is clear in most cases. For the years following 2002, the peak flows of the floods are low with a more developed vegetation cover. On the other hand, the floods of the years before 2002 are characterized by higher peak flows and a weak vegetation cover. It can be argued that when the latter is dense, part of the precipitated water is absorbed and therefore the quantity of water that will contribute to direct runoff will be reduced. However, vegetation plays an important role in attenuating flooding. When the vegetation is developed the runoff is delayed and the flood peak is attenuated. Moreover, the flow being longer, the share of infiltration water increases and the volume of flood decreases.

\section{CONCLUSIONS}

The use of modeling as a tool to find the link between land use and hydrological process is a better method recognized as both simple and productive. From a digital terrain model, Landsat 
images, soil and geological maps, the different parameters necessary for the hydrological simulation were determined.

The present study focused on the use of a rainfall-runoff model to show the effect of the change of land-use on the hydrological functioning of the Upper Oum Er Rbia basin and to predict the peak flows in case of flood, especially upstream of the city Khénifra (Tahrat Station).

The modeling step was preceded by the elaboration of land cover and soil type maps according to NRCS rules. The classification of Landsat satellite images allowed the identification of five land cover classes (bare soil, water surface, dense forest, less dense and sparse). The soil data for the study area was transformed from a texture-based terminology to a hydrological HGS terminology, which was then used to create the Curve Number (CN) map using the HEC-GeoHMS model. The final Curve Number map shows an average $\mathrm{CN}$ of 69 ; this means that the basin has moderately high runoff. The set of optimized parameters to validate the estimated peak flows at the outlet of the upper Oum Er Rbia basin was deduced based on 4 events.

The results of the land cover mapping show a clear increase in vegetation cover of $6.21 \%$. The application of the rainfall-runoff model in the basin shows a positive correlation between observed and simulated flows. The model is satisfactorily calibrated with a NSE value of 0.79 .

\section{REFERENCES}

1. Bouabdelli, M., Piqué, A., 1996. Du bassin sur décrochement au bassin d'avant-pays: dynamique du Bassin d'Azrou-Khénifra (Maroc hercynien central). Journal of African Earth Sciences, 23, 213-224.

2. Carlson, T.N., and Arthur, S.T., 2000. The impact of land use land cover changes due to urbanization on surface microclimate and hydrology: a satellite perspective. Global and Planetary Change, 25, 49-65.

3. Chaponnière, A., 2005. Fonctionnement hydrologique d'un bassin versant montagneux semiaride : cas du bassin versant du Rehraya (Haut Atlas marocain), thèse de doctorat, INA Paris-Grigon, (France), pp. 233.

4. Dregne, H.E., 1991. Human activities and soil degradation. Semiarid Lands and Deserts: Soil Resource and Reclamation 19, 335.

5. Driouech, F., 2010. Distribution des précipitations hivernales sur le Maroc dans le cadre d'un changement climatique : descente d'échelle et incertitudes, thèse de doctorat, GAME Toulouse, (France), pp.164.
6. El Ghachi, M., Morchid, 2018. Analyse des tendances pluviométriques dans la ville de Khénifra dans un contexte de variabilité climatique (Rainfall trend analysis in Khenifra city in a context of climate variability). J. Water Environ. Sci. 2, 297-304.

7. Ezeaku, P.I., Davidson, A., 2008. Analytical situations of land degradation and sustainable management strategies in Africa. Journal of Agriculture \& Social Sciences, 4, 42-52.

8. Feldman, A.D., 2000. HEC-HMS Technical Reference Manual; US Army corps of engineers R\&D Woek Unit, Report, pp. 148.

9. Gilmore, S., Saleem, A., Dewan, A., 2015. Effectiveness of DOS (Dark-Object Subtraction) method and water index techniques to map wetlands in a rapidly urbanising megacity with Landsat 8 data. Research@ Locate'15, 100-108.

10. Hansen, M.C., Loveland, T.R., 2012. A review of large area monitoring of land cover change using Landsat data. Remote Sensing of Environment, Landsat Legacy Special Issue 122, 66-74.

11. Kingumbi, A. 2006. Modélisation hydrologique d'un bassin versant affecté par des changements d'occupation. Cas du Merguellil en Tunisie centrale. Thèse de Doctorat de l'Ecole Nationale d'Ingénieurs de Tunis, Tunisie, pp. 199.

12. Kosmas, C., Danalatos, N., Cammeraat, L.H., Chabart, M., Diamantopoulos, J., Farand, R., Gutierrez, L., Jacob, A., Marques, H., Martinez-Fernandez, J., 1997. The effect of land use on runoff and soil erosion rates under Mediterranean conditions. Catena, 29, 45-59.

13. Kumar, S., Shwetank, Jain, K., 2020. A Multi-Temporal Landsat Data Analysis for Land-use/Landcover Change in Haridwar Region using Remote Sensing Techniques. Procedia Comput. Sci. 171, 1184-1193.

14. Laborde, J.P., 2000. Eléments d'hydrologie de surface. Université de Nice-Sophia Antipolis. France, pp. 204.

15. Loumagne, C., Michel, C., Normand, M., 1991. Etat hydrique du sol et prévision des débits. Journal of Hydrology, 123, 1-17.

16. Marchandise, A. (2007). Modélisation hydrologique distribuée sur le Gardon d'Anduze ; étude comparative de différents modèles pluie-débit, extrapolation de la normale à l'extrême et tests d'hypothèses sur les processus hydrologiques. Thèse de Université de Montpellier II, Montpellier. pp. 214.

17. McCuen, R.H., Knight, Z., Cutter, A.G., 2006. Evaluation of the Nash-Sutcliffe efficiency index. Journal of Hydrologic Engineering, 11, 597-602.

18. Muthu, A.L., Santhi, M.H., 2015. Estimation of surface runoff potential using SCS-CN method integrated with GIS. Indian J. Sci. Technol., 8. 
19. Musy, A., and Higy, C., 1998. Hydrologie appliquée (Edition $\mathrm{H}^{*} \mathrm{G}^{*} \mathrm{~A}$ ). pp. 368.

20. Obodai, J., Adjei, K.A., Odai, S.N., Lumor, M., 2019. Land use/land cover dynamics using Landsat data in a gold mining basin-the Ankobra, Ghana. Remote Sensing Applications: Society and Environment, 13, 247-256.

21. Pachauri, R.K., Meyer, L., Plattner, G.-K., Stocker, T., others, 2015. IPCC, 2014: Climate Change 2014: Synthesis Report. Contribution of Working Groups I, II and III to the Fifth Assessment Report of the Intergovernmental Panel on Climate Change. IPCC, pp. 151.

22. Rey, F., Ballais, J.-L., Marre, A., Rovera, G., 2004. Rôle de la végétation dans la protection contre l'érosion hydrique de surface. Comptes rendus géoscience, 336, 991-998.
23. Smits, A.J.M., Nienhuis, P.H., Leuven, R.S.E.W., 2000. New approaches to river management. Environmental Management and Health, 11, 474-475.

24. Uwizeyimana, D., Mureithi, S.M., Mvuyekure, S.M., Karuku, G., Kironchi, G., 2019. Modelling surface runoff using the soil conservation servicecurve number method in a drought prone agroecological zone in Rwanda. International Soil and Water Conservation Research, 7, 9-17.

25. Yjjou, M., Bouabid, R., El Hmaidi, A., Essahlaoui, A., El Abassi, M., 2014. Modélisation de l'érosion hydrique via les SIG et l'équation universelle des pertes en sol au niveau du bassin versant de l'Oum Er-Rbia. The International Journal of Engineering and Science, 3, 83-91. 